\title{
ANALISIS KEBIJAKAN PEMBELAJARAN DARING TERHADAP EVALUASI BELAJAR SISWA
}

\author{
1 Umu Kurnia Nur Hidayah, ${ }^{2}$ M. Yunus Abu Bakar \\ 1,2 Universitas Hasyim Asy'ari Tebuireng Jombang \\ 1UmmukurniaNH@gmail.com, 2elyunusy@gmail.com
}

\begin{abstract}
This study aims to identify the analysis of online learning policies on student learning evaluations. This type of research is qualitative, namely research that produces descriptive data in the form of written or spoken words from people and observed behavior. The technique of collecting and collecting data in this study was carried out through: observation, interviews, and documentation. The analytical method used is a qualitative analysis method.

The result of this study is that the online learning evaluation has not fully reached the minimum completeness criteria (KKM) target as determined. In some subjects, it has fulfilled the KKM, and some students have not fulfilled the KKM. For students who have not met the grades, a remedial test is carried out so that the evaluation and grades can meet the expected targets.
\end{abstract}

\section{ABSTRAK}

Penelitian ini bertujuan untuk mengidentifikasi analissi kebijakan pembelajaran daring terhadap evaluasi belajar siswa. Jenis penelitian ini adalah kualitatif yakni penelitian yang menghasilkan data deskriptif berupa kata-kata tertulis atau lisan dari orang-orang dan perilaku yang diamati. Teknik pengambilan dan pengumpulan data dalam penelitian ini dilakukan melalui: observasi, wawancara, dan dokumentasi. Adapun metode analisis yang digunakan adalah metode analisis kualitatif.

Hasil dari penelitian ini yaitu bahwa evaluasi pembelajaran yang dilaksanakan secara daring belum sepenuhnya mencapai target Kriteria

ARTICLE HISTORY
Received 28 Januari 2021
Revised 18 Maret 2021
Accepted 23 Maret 2021
KEYWORDS
$\begin{aligned} & \text { Online learning, Learning } \\ & \text { evaluation }\end{aligned}$


Ketuntasan Minimal (KKM) sebagaimana yang sudah ditentukan. Pada sebagian mata pelajaran memang sudah memenuhi KKM sebagian lagi masih ada siswa yang belum memenuhi KKM. Bagi siswa yang belum memenuhi nilai maka dilakukan remedial tes agar evaluasi dan nilai dapat memenuhi target yang diharapkan.

\section{PENDAHULUAN}

Pendidikan merupakan suatu usaha proses untuk memperoleh dan memperdalam ilmu pengetahuan. Hidayat \& Patras mengatakan bahwa "kemajuan dari suatu bangsa dapat dilihat dari tingkatan ilmu pendidikan". Sehingga dengan sadar bahwa pendidikan tersebut bernilai penting, membuat perubahan dalam kehidupan setiap individu. Hal ini membantu setiap individu terlepas dari kemiskinan, keterbelakangan, kebodohan, serta ketertindasan dan perang. Dengan mempelajari dan memperdalam pendidikan yang setinggitingginya membuat arah kehidupan yang layak dan lebih baik lagi. Wardhani menyatakan bahwa "dengan adanya pendidikan, memiliki tujuan untuk mengembangkan kepribadian yang berakhlak mulia dan keterampilan yang diperlukan di dalam anggota masyarakat. Sehingga pendidikan dapat diartikan memiliki peran besar dalam kehidupan individu".

Organisasi Kesehatan Dunia (WHO) menyatakan COVID-19 darurat global pada 30 Januari 2020 dan pandemi global pada 11 Maret 2020. Saat ini, COVID-19 memengaruhi 213 negara dan wilayah (WHO, 2020). Menanggapi COVID-19, beberapa negara telah menerapkan langkah-langkah jarak sosial yang ketat dan kebijakan penguncian. Jelas, pandemi ini telah memiliki dampak yang luar biasa pada sekolah, siswa dan guru. Pada tanggal 12 Maret 2020, 46 negara di lima benua yang berbeda telah menyatakan penutupan sekolah dan 26 dari negara-negara ini telah sepenuhnya menutup sekolah secara nasional Di Indonesia, Pemerintah telah membatasi mobilisasi masyarakat dalam upaya mencegah penyebaran penyakit dan terus mempromosikan agenda: bekerja dari rumah, belajar dari rumah dan ibadah di 
rumah. Sekolah dan Lembaga Pendidikan Tinggi (HEI) di Indonesia telah ditutup sementara sejak 14 Maret 2020. Untuk menangani penutupan sekolah dan HEI di Indonesia, proses pengajaran dan pembelajaran telah dipertahankan dari jarak jauh menggunakan Teknologi Informasi dan Komunikasi (ICT). Pembelajaran elektronik (e-learning) telah dianggap sebagai pendekatan terbaik untuk melanjutkan proses pengajaran dan pembelajaran selama pandemi. Di Indonesia, platform e-learning yang direkomendasikan oleh pemerintah adalah Rumah Belajar dan SPAD. Rumah Belajar adalah platform pembelajaran online gratis yang dikembangkan oleh Kementerian Pendidikan dan Kebudayaan Indonesia sebagai sumber belajar alternatif bagi guru sekolah dan siswa. SPADA adalah platform e-learning yang dikembangkan oleh Kementerian Riset, Teknologi, dan Pendidikan Tinggi untuk HEI. Selain itu, Kementerian Pendidikan dan Kebudayaan Indonesia bermitra dengan beberapa aplikasi pembelajaran daring. Semua sumber daya ini mendukung siswa dan guru agar siswa dapat belajar dari rumah. ${ }^{1}$

Menurut Isman pembelajaran daring merupakan pemanfaatan jaringan internet dalam proses pembelajaran. Dengan pembelajaran daring siswa memiliki keleluasaan waktu belajar, dapat belajar kapanpun dan dimanapun. Siswa dapat berinteraksi dengan guru menggunakan beberapa aplikasi seperti classroom, video converence, telepon atau live chat, zoom maupun melalui whatsapp group. $^{2}$

Pembelajaran ini merupakan inovasi pendidikan untuk menjawab tantangan akan ketersediaan sumber belajar yang variatif. Keberhasilan dari suatu model ataupun media pembelajaran tergantung dari karakteristik peserta didiknya. Sebagai mana yang diungkapkan oleh Nakayama bahwa dari semua literatur dalam elearning mengindikasikan bahwa tidak semua peserta didik

\footnotetext{
1 Pretty Sinambela, Sigit Suhada, and Ganjar Susilo, "Analisis Mengenai Dampak Penghapusan Ujian Nasional Terhadap Kelulusan Peserta Didik Jenjang SMP Di Era Pandemik Covid-19," no. 30 (2020): hlm. 281-290.

2 Wahyu Aji Fatma Dewi, “Dampak COVID-19 Terhadap Implementasi Pembelajaran Daring Di Sekolah Dasar," Edukatif: Jurnal Ilmu Pendidikan 2, no. 1 (2020): hlm. 55-61.
} 
akan sukses dalam pembelajaran online. Ini dikarenakan faktor lingkungan belajar dan karakteristik peserta didik.

Dengan adanya kasus pandemi covid-19 ini, maka sekolah diseluruh indonesi menggunakan pembelajaran daring. Pembelajaran daring merupakan langkah kebijakan yang dapat diambil pemerintah dalam pemerataan kualitas pendidikan di wilayah Indonesia. Untuk itu dari fenomena tersebut peneliti tertarik untuk melakukan sebuah penelitian untuk mengungkapkan bagaimana proses pembelajaran daring sendiri terhadap hasil akhir belajar siswa selama pembelajaran itu berlangsung dengan melakukan penelitian dan membahas hal tersebut dengan judul "ANALISIS PEMBELAJARAN DARING TERHADAP EVALUASI BELAJAR SISWA".

\section{METODE PENELITIAN}

Jenis penelitian ini adalah kualitatif yakni penelitian yang menghasilkan data deskriptif berupa kata-kata tertulis atau lisan dari orang-orang dan perilaku yang diamati. ${ }^{3}$

Atau dengan kata lain penelitian kualitatif adalah penelitian yang mengkaji data secara mendalam tentang semua kompleksitas yang ada dalam konteks penelitian tanpa menggunakan skema berpikir statistik.

Menurut Ridwan menyatakan bahwa sebuah penelitian yang dimulai karena adanya masalah, dan masalah ini pada umumnya dimiliki oleh para administrator, menajer atau para pengambil keputusan padasuatu organisasi dinamakan penelitian kebijakan (policy reseach).

Penelitian kebijakan adalah suatu proses penelitian yang dilakukan pada masalahmasalah sosial yang mendasar, sehingga hasil temuannya dapat direkomendasikan kepada pembuat keputusan untuk bertindak secara praktis dalam menyelesaikan kasus-kasus ditempat kerjanya.

\footnotetext{
${ }^{3}$ Lexy J Moleong, Metodologi Penelitian Kualitatif (Bandung: Remaja Rosdakarya, 2009), hlm. 4.
} 
Teknik pengambilan dan pengumpulan data dalam penelitian ini dilakukan melalui: observasi, wawancara, dan dokumentasi. Adapun metode analisis yang digunakan adalah metode analisis kualitatif.

\section{HASIL DAN PEMBAHASAN}

Coronavirus adalah keluarga besar virus yang menyebabkan penyakit mulai dari gejala ringan sampai berat. Ada setidaknya dua jenis coronavirus yang diketahui menyebabkan penyakit yang dapat menimbulkan gejala berat seperti Middle East Respiratory Syndrome (MERS) dan Severe Acute Respiratory Syndrome (SARS). Coronavirus Diseases 2019 (COVID-19) adalah penyakit jenis baru yang belum pernah diidentifikasi sebelumnya pada manusia. Tanda dan gelaja umum infeksi COVID-19 antara lain gejala gangguan pernapasan akut seperti demam, batuk, dan sesak napas. Masa inkubasi rata-rata 5-6 hari dengan masa inkubasi terpanjang 14 hari.

Penyebaran virus corona ini pada awalnya sangat berdampak pada dunia ekonomi yang mulai lesu, tetapi kini dampaknya dirasakan juga oleh dunia pendidikan. Kebijakan yang diambil oleh banyak negara termasuk Indonesia dengan meliburkan seluruh aktivitas pendidikan, membuat pemerintah dan lembaga terkait harus menghadirkan alternatif proses pendidikan bagi peserta didik maupun mahasiswa yang tidak bisa melaksanakan proses pendidikan pada lembaga pendidikan.

Aktivitas yang melibatkan kumpulan orang-orang kini mulai dibatasi seperti bersekolah, bekerja, beribadah dan lain sebagainya. Pemerintah sudah mengimbau untuk bekerja, belajar, dan beribadah dari rumah untuk menekan angka pasien yang terpapar COVID-19. Menteri Nadiem Anwar Makarim menerbitkan Surat Edaran Nomor 3 Tahun 2020 pada Satuan Pendidikan dan Nomor 36962/MPK.A/HK/2020 tentang Pelaksanaan Pendidikan dalam Masa Darurat Coronavirus Disease (COVID-19) maka kegaiatan belajar dilakukan secara daring (online) dalam rangka pencegahan penyebaran coronavirus disease (COVID-19). 
(Menteri Pendidikan, 2020) Dengan munculnya pandemik COVID-19 kegiatan belajar mengajar yang semula dilaksanakan di sekolah kini menjadi belajar di rumah melalui daring. ${ }^{4}$ Menurut Bilfaqih \& Qomarudin pembelajaran daring merupakan program penyelenggaraan kelas pembelajaran dalam jaringan untuk menjangkau kelompok target yang masif dan luas. ${ }^{5}$ Pembelajaran daring dilakukan dengan disesuaikan kemampuan masingmaisng sekolah. Belajar daring (online) dapat menggunakan teknologi digital seperti google classroom, rumah belajar, zoom, video converence, telepon atau live chat dan lainnya. Namun yang pasti harus dilakukan adalah pemberian tugas melalui pemantauan pendampingan oleh guru melalui whatsapp grup sehingga anak betul-betul belajar. Kemudian guru-guru juga bekerja dari rumah dengan berkoordinasi dengan orang tua, bisa melalui video call maupun foto kegiatan belajar anak dirumah untuk memastikan adanya interaksi antara guru dengan orang tua.

Beberapa sekolah yang belum dapat menyelenggarakan KBM daring dapat mengembangkan kreativitas guru untuk memanfaatkan media belajar alternatif selama peserta didik belajar di rumah. Mereka dapat menggunakan sumber belajar yang ada yaitu buku siswa sesuai dengan tema-tema yang diajarkan sesuai jadwal yang telah dibuat sebelumnya.

Dalam pelaksanaan pembelajaran untuk menentukan berhasil tidaknya suatu pembelajaran maka dilakukanlah evaluasi sebagai langkah penentu keberhasilan suatu kegiatan belajar mengajar. Evaluasi belajar dan pembelajaran adalah proses untuk menentukan nilai belajar dan pembelajaran yang dilaksanakan, dengan melalui kegiatan penilaian atau pengukuran belajar dan pembelajaran. Sedangkan pengertian pengukuran dalam kegiatan pembelajaran adalah proses membandingkan tingkat keberhasilan belajar dan pernbelajaran dengan ukuran keberhasilan belajar dan pembelajaran yang telah

\footnotetext{
${ }^{4}$ Dewi, "Dampak COVID-19 Terhadap Implementasi Pembelajaran Daring Di Sekolah Dasar," hlm. 56-61.

5 Yusuf Bilfaqih and M. Nur Qomarudin, Esensi Penyusunan Materi Pembelajaran Daring (Yogyakarta: Deepublish, 2015), hlm. 1.
} 
ditentukan secara kuantitatif sementar pengertian penilaian belajar dan pembelajaran adalah proses pembuatan keputusan nilai keberhasilan belajar dan pembelajaran secara kualitatif. ${ }^{6}$ Sama halnya dalam pembelajaran yang dilaksanakan secara daring sebagai wujud bentuk penentu keberhasilannya maka dilakukanlah evaluasi yang berupa pemberian tugas yang diberikan guru dengan bantuan google classroom, rumah belajar, zoom, video converence, telepon atau live chat dan lainnya. Beberapa media online tersebut merupakan alat yang berguna untuk membantu merencanakan acara, mengirim survei, memberikan siswa atau oranglain kuis atau mengumpulkan infromasi dengan cara yang efisien. Tak hanya lewat daring pemberian tugas juga dilakukan guru secara langsung bagi orangtua yang belum mempunyai dan tidak bisa mengoperasikan ponsel dengan menyuruh orangtua untuk mengambilnya disekolah kemudian dikerjakan siswa dirumah masing - masing.

Berdasarkan penelitian yang telah dilaksanakan bahwa evaluasi pembelajran yang dilaksanakan secara daring belum sepenuhnya mencapai target Kriteria Ketuntasan Minimal (KKM) sebagaimana yang sudah ditentukan. Kriteria Ketuntasan Minimal (KKM) adalah kriteria paling rendah untuk menyatakan peserta didik mencapai ketuntasan dalam menentukan kelulusan peserta didik. Kriteria ketuntasan minimal ditetapkan oleh satuan pendidikan berdasarkan hasil musyawarah guru mata pelajaran disatuan pendidikan

Pada sebagian mata pelajaran memang sudah memenuhi KKM sebagian lagi masih ada siswa yang belum memenuhi KKM sebagaimana yang dijelaskan guru dalam wawancara sebelumnya. Sebagai langkahnya guru melakukan remedial tes bagi siswa yang belum memenuhi KKM agar evaluasi pembelajarannya sesuai dengan tujuan yang diharapkan.

\footnotetext{
${ }^{6}$ B. Mahirah, "Evaluasi Belajar Peserta Didik (Siswa)," Idaarah: Jurnal Manajemen Pendidikan 1, no. 2 (2017): hlm. 259.
} 


\section{KESIMPULAN}

Berdasarkan hasil penelitian dan pembahasan di atas bahwa evaluasi pembelajaran yang dilaksanakan secara daring belum sepenuhnya mencapai target Kriteria Ketuntasan Minimal (KKM) sebagaimana yang sudah ditentukan. Pada sebagian mata pelajaran memang sudah memenuhi KKM sebagian lagi masih ada siswa yang belum memenuhi KKM. Bagi siswa yang belum memenuhi nilai maka dilakukan remedial tes agar evaluasi dan nilai dapat memenuhi target yang diharapkan.

\section{DAFTAR PUSTAKA}

Bilfaqih, Yusuf, and M. Nur Qomarudin. Esensi Penyusunan Materi Pembelajaran Daring. Yogyakarta: Deepublish, 2015.

Dewi, Wahyu Aji Fatma. "Dampak COVID-19 Terhadap Implementasi Pembelajaran Daring Di Sekolah Dasar." Edukatif: Jurnal Ilmu Pendidikan 2, no. 1, 2020.

Mahirah, B. "Evaluasi Belajar Peserta Didik (Siswa)." Idaarah: Jurnal Manajemen Pendidikan, 1, no. 2, 2017.

Moleong, Lexy J. Metodologi Penelitian Kualitatif. Bandung: Remaja Rosdakarya, 2009.

Sinambela, Pretty, Sigit Suhada, and Ganjar Susilo. "Analisis Mengenai Dampak Penghapusan Ujian Nasional Terhadap Kelulusan Peserta Didik Jenjang SMP Di Era Pandemik Covid-19," no. 30 (2020). 